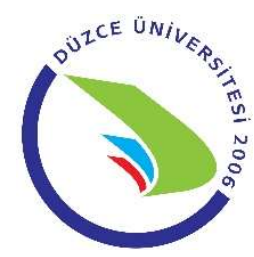

\title{
Sağlık Çalışanlarının Kadına Yönelik Şiddeti Tanımalarına İlişkin Bilgi Düzeylerinin Belirlenmesi
}

\author{
Pınar KARA ${ }^{1}$, Öznur AKÇAYÜZLÜ², Ali Özcan GÜR², Evşen NAZİK
}

\section{Öz}

Amaç: Araştırma, aile sağlı̆̆ı merkezlerinde çalışan sağlık çalışanlarının kadına yönelik şiddeti tanımalarına ilişkin bilgi düzeylerinin belirlenmesi amaciyla yapılmıştır.

Gereç ve Yöntemler: Tanımlayıcı kesitsel nitelikteki çalışma, Kasım 2015-Mart 2016 tarihleri arasında Adana'da bir Toplum Sağlığı Merkezine bağlı 20 Aile Sağlığı Merkezi'nde çalışan ve katılmayı kabul eden 135 kişi (13 hemşire, 66 hekim, 56 ebe) ile yapılmıştır. Verilerin toplanmasında; "Kişisel Bilgi Formu" ve "Hemşire ve Ebelerin Kadına Yönelik Şiddet Belirtilerini Tanımalarına İlişkin Ölçek (HEKYŞBTÖ)"; analizinde SPSS 16.0 istatistik paket programı, değerlendirilmesinde; yüzdelik dağılımlar, $t$ testi, Mann Whitney U testi ve Kruskal Wallis H testi kullanılmıstır.

Bulgular: Sağlık çalı̧̧anlarının yaş ortalamasının $45.33 \pm 7.69$ (en düşük-en yüksek: 26-66), \%62.2'sinin kadın ve \%90.4'ünün evli olduğu belirlenmiştir. Katılımcıların \%48.9'unun hekim, \%41.5'inin ebe, \%9.6'sının hemşire olduğu, \%97'sinin 5 yıldan daha fazla süredir çalıştı̆̆ı saptanmıştır. Sağlık çalışanlarının \%84.4'ünün mezuniyet öncesi, \%83.7'sinin mezuniyet sonrası kadına yönelik şiddet konusunda eğitim almadığı bulunmuştur. Katılımcıların \% 72.6 'sının iş yaşamında kadına yönelik şiddet olgusu ile karşılaştı̆̆,$\% 55.1$ 'inin ilgili kurumlara rapor etme/yasal süreçte, \%24.5'inin öykü almada zorlandığı saptanmıştır. Sağlık çalışanlarının HEKYŞBTÖ toplam puan ortalaması 19.06 \pm 3.68 , fiziksel belirtiler alt boyut puan ortalaması $8.07 \pm 1.68$, duygusal belirtiler alt boyut puan ortalaması $10.99 \pm 2.66$ olarak belirlenmiş̧tir. HEKYŞBTÖ ile sağlık çalışanlarının sosyodemografik ve mesleki özellikleri arasında istatistiksel olarak anlamlı bir fark bulunmamıştır ( $p>0.05$ ).

Sonuç: Aile Sağlığı Merkezlerinde çalışan sağlık profesyonellerinin kadına yönelik şiddet belirtilerini tanımalarına ilişkin bilgi düzeylerinin kısmen yeterli olduğu saptanmıştır.

Anahtar Kelimeler: Şiddet; kadın; hemşire; hekim; ebe.

\section{Determination of Knowledge Levels Associated with Recognition of Violence against Women of Health Professionals}

\section{ABSTRACT}

Aim: The study was performed to determine of knowledge levels associated with recognition of violence against women of health professionals working in family health centers.

Material and Methods: This descriptive cross-sectional study was conducted with 135 people (13 nurses, 66 physicians, 56 midwives) working in 20 Family Health Centers in Adana between November 2015 and March 2016. In data collection was used "Personal Information Form" and "Scale of Concerning Nurses and Midwives' Recognition of Violence against Women (NMRVAWS). In data analysis, SPSS 16.0 statistical package program; evaluating percentile distributions, $t$ test, Mann Whitney U test and Kruskal Wallis H test.

Results: It was determined that average age of health workers was $45.33 \pm 7.69$ (min-max: $26-66$ ), $62.2 \%$ was females and $90.4 \%$ was married. It was determined that $48.9 \%$ participants' was physicians, $41.5 \%$ was midwives, $9.6 \%$ was nurses, $97 \%$ was working more than 5 years. It was found that $15.6 \%$ health workers' was educated on pre-graduation, $16.3 \%$ on post-graduation violence against women. It was detected $72.6 \%$ had come across violence against women in business life, $51.1 \%$ reporting to related institutions / legal process and $24.5 \%$ have difficulty in taking women story. The total average score of NMRVAWS was $19.06 \pm 3.68$, mean scores of physical symptoms subscale was $8.07 \pm 1.68$, mean scores of emotional symptom subscale was $10.99 \pm 2.66$. There was not statistically insignificant difference between NMRVAWS and socio-demographic and professional factors ( $\mathrm{p}>0.05)$.

Conclusion: The level of knowledge health professionals' working in Family Health Centers is partially adequate about identifying violence against women.

Keywords: Violence; woman; nurse; doctor; midwife.

\footnotetext{
1 Niğde Ömer Halisdemir Üniversitesi, Niğde Zübeyde Hanım Sağlık Yüksekokulu

2 Çukurova Üniversitesi Sağlık Bilimleri Fakültesi

Sorumlu Yazar / Corresponding Author: Pınar KARA, 01pinarkara@gmail.com

Geliş Tarihi / Received: 09.07.2018～Kabul Tarihi / Accepted: 03.09.2018
}

Bu çalışma, 15. Uluslararası Doğu Akdeniz Aile Hekimliği Kongresi, 3. Uluslararası Doğu Akdeniz Hemşirelik Kongresi 'nde sözlü bildiri olarak sunulmustur. 26-29 Mayıs 2016 - Adana. 


\section{GIRIŞ}

Şiddet insan yaşamının her alanında görülebilen ve dünyada hızlı artış gösteren önemli bir toplum sağlığ sorunudur (1). Şiddet genel anlamda, sahip olunan güç veya kudretin bir başka insana, kendine, bir gruba, topluma karşı yaralanma veya kayıpla sonlanma olasılı̆̆ı yüksek biçimde uygulanmasıdır (2,3). Dünya Sağlık Örgütü'nün tanımıyla şiddet; fiziksel güç ya da kuvvetin, amaçlı bir şekilde kendine, başkasına, bir gruba ya da topluluğa karşı fiziksel zarara ya da fiziksel zararla sonuçlanma ihtimalini artırmasına, psikolojik zarara, ölüme, gelişim sorunlarına ya da yoksunluğa neden olacak şekilde tehdit edici biçimde ya da gerçekten kullanılmasıdır (4).

Şiddet zamana ve sosyal yapıya göre değişen bir kavram olmasına rağmen, son yillarda en fazla dikkat çeken konulardan biri olmuştur. En büyük mağduru ise kadınlardır. Toplumsal cinsiyet eşitsizliğine bağlı olarak yaşanan, insan hakları ihlali ve kadınlara yönelik ayrımcılık biçimlerinden biri olan kadına yönelik şiddet, dünya çapında önemli ve sosyal bir sağlık problemi olarak düşünülmektedir. Çağlardır süregelen, kadınla erkek arasında eşit olmayan güç ilişkilerinin bir yansıması olan kadına yönelik şiddet; ağır bir insan hakkı ihlali ve ciddi bir toplumsal sorun olarak, kültürel, ekonomik, coğrafi sınır tanımaksızın tüm dünyada varlığını sürdürmektedir (5). Kadının fiziksel, cinsel veya psikolojik zarar görmesiyle veya acı çekmesiyle sonuçlanması muhtemel olan, ister toplum önünde, ister özel hayatta meydana gelmiş olsun cinsiyete dayalı her türlü ayrımcılık şiddet olarak kabul edilmektedir (6).

Kadına yönelik şiddet genellikle fiziksel, cinsel, sözel, ekonomik ve duygusal (psikolojik) şiddet olmak üzere 5 grupta kategorize edilmektedir. DSÖ kadınların yaklaşık $\% 35$ 'inin (her 3 kadından 1 'inin) fiziksel veya cinsel şiddete maruz kaldığını, kadın cinayetlerinin \%38'inin kadınların eşi veya birlikte yaşadığı kişi tarafından işlendiğini belirtmektedir (4). Türkiye'de Kadına Yönelik Aile İçi Şiddet Araştırması 2014 yılı Raporunda (6); kadınların \%36'sının fiziksel şiddete, \%12'sinin cinsel şiddete, \%44'ünün duygusal şiddete ve \%30'unun ekonomik şiddete maruz kaldığı bildirilmektedir. Ayrıca raporda, eğitim düzeyi düşük olanların, erken yaşta evlenenlerin, gelir düzeyi düşük olanların ve kırsal alanda yaşayanların daha fazla şiddete uğradıkları ifade edilmektedir.

Temel insan hakları ihlali olarak varlığını sürdüren kadına yönelik şiddet, kadınların beden ve ruh sağlığını bozan, sosyal, ekonomik, kültürel konumlarını ve bu alanlarda yükselmelerini engelleyen ciddi bir halk sağlığı sorunudur. Şiddet sonrasında her kadın bedenen, ruhen ve sosyal açıdan son derece olumsuz şekilde etkilenmektedir. Şiddet kadını öz kıyıma sürükleyebilmekte, cinayete kurban gitmesine neden olabilmektedir. Ayrıca iş yaşamını olumsuz etkilerken veya sona erdirirken, kadını yoksulluğa ve ekonomik bağımsızlığını kaybetmeye de itmektedir (7-10).

Birçok toplum gibi bizim toplumumuzda da erkeklerin lider, kahraman, savaşçı; kadınların değersiz, köle gibi algılanması erkeklerin kadınlardan daha güçlü ve saygın olarak kabul edilmesine neden olmuştur. Bu algı ile oluşturulan eşitsiz güç erkeklerin saldırgan davranışlarına ve kadına yönelik şiddetine gerekçe oluşturmuştur $(9,11,12)$.
Sağlık arayan kadınlar arasında eşi ve/veya sevgilisi tarafından uygulanan şiddet yaygınlığı genel nüfustan daha fazladır (13). Fiziksel şiddete uğrayan kadınların psikiyatri, acil servis, jinekoloji kliniği, hastane, birinci basamak sağlık kurumları ve eczaneleri daha sık kullandıkları görülmektedir (14). Birinci basamakta yapılan bir araştırmada, kadınların \%41'inin fiziksel şiddet mağduru olduğu ya da yaşam boyu fiziksel şiddete maruz kaldığı belirtilmektedir (15). Ülkemizde bir Adli Tıp Polikliniği'ne başvuran kadınların \%71.7'sine eşi/sevgilisinin (16), 17-59 yaşlar arasındaki evli kadınların \%61.4'üne eşinin şiddet uyguladığı belirlenmiştir (17).

DSÖ şiddeti kadın sağlığı sorunları arasında saymaktadır (4). Şiddet mağdurlarına tıbbi bakım, destek ve danışmanlık sunmada sağlık çalışanlarının anahtar konumda olması beklenmektedir. Ülkemizde Sağlık Bakanlığı'na bağlı olarak çalışan Aile Sağlığı Merkezleri (ASM), Toplum Sağlığı Merkezleri (TSM) ve hastaneler kadına yönelik şiddet konusunda hizmet vermektedir (18). Aynı zamanda, Sağlık Bakanlığı'nın 2016-2020 kadına yönelik şiddetle mücadele eylem planında şiddete uğrayan ve uğrama tehlikesi bulunan kadınlara ulaşılabilir koruyucu ve önleyici hizmetlerin daha etkili verilmesi ve yaygınlaştırılması, şiddete uğrayan kadına yönelik sağlık hizmetlerinin düzenlenmesi ve uygulanmasının sağlanması temel hedefleri oluşturmaktadır (12). Şiddeti tanımak, bakımını sağlamak, şiddet mağdurlarına uygun hizmetleri sunmak, sağlık çalışanlarının rolleri arasında yer almaktadır (19). Sağlık profesyonellerinin şiddet mağdurlarına toplumda kullanabilecekleri kaynaklar, sosyal destek sistemleri ve iletişim ağları ile ilgili bilgi vermeleri gerekmektedir (12). Bu konuda her sağlık çalışanına ayrı ayrı sorumluluklar düşmektedir. Hekimler, hasta ile karşılaştığında hastanın ve koşullarının durumunu ayrıntılı olarak değerlendirme ve hastanın yararına olan her şeyi yapmakla yükümlü olan sağlık elemanlarıdır (20). Ebe ve hemşirelerin ise savunuculuk, danışmanlık, eğitim ve bakım rollerinin gereği, kadının, ailenin ve toplumun sağlığının korunması ve iyileştirilmesi, gerektiğinde rehabilitasyonunu sağlama işlevleri bulunmaktadır (3).

Sağlık merkezlerinde çalışan sağlık personeli şiddet mağdurlarının ilk iletişim kurduğu temel yardım kaynağıdırlar ve kadına yönelik şiddeti tanılamada önemli bir rol üstlenmelidirler. Özellikle aile içi şiddet çoğunlukla gizli tutulduğu için şiddetin farkına varılması ve şiddet olasılığının değerlendirilmesi durumun ortaya çıkarılmasında önemlidir (1).

$\mathrm{Bu}$ çalışma, aile sağlığı merkezlerinde görev yapan sağlık çalışanlarının kadına yönelik şiddeti tanımalarına ilişkin bilgi düzeylerinin belirlenmesi amacıyla yapılmıştır.

\section{GEREÇ VE YÖNTEMLER}

Tanımlayıcı ve kesitsel nitelikteki bu araştırma Kasım 2015-Mart 2016 tarihleri arasında Adana'da bir Toplum Sağlığı Merkezi'ne (TSM) bağlı 20 Aile Sağlığı Merkezi'nde (ASM) yapılmıştır.

\section{Araştırmanın Evreni ve Örneklemi}

Araştırmanın evrenini, ilgili tarihler arasında Adana'da bir Toplum Sağlığı Merkezi'ne bağlı 20 Aile Sağlığı Merkezi'nde çalışan 95 hekim, 95 hemşire ve ebe olmak üzere toplam 190 kişi oluşturmuştur. Örneklem seçimine gidilmemiş, evrenin tamamına ulaşılmaya çalışılmıştır. 
Ancak çalışma araştırmaya katılmayı kabul eden 13 hemşire, 56 ebe ve 66 hekim olmak üzere toplam 135 kişiyle tamamlanmıştır (Katılım oranı=\%71).

\section{Araştırmanın Etik Boyutu}

Araştırmaya başlamadan önce Çukurova Üniversitesi Tıp Fakültesi Etik Kurulundan 2015/47 protokol nolu onay ve araştırmanın yapıldığı kurumlardan yazılı izinler alınmıştır. Ayrıca katılımcılara anket uygulaması öncesinde çalışma hakkında bilgi verilmiş ve sözlü onamları alınmıştır. Araştırmanın verileri sağlık çalışanlarının öz bildirimine dayanmaktadır.

\section{Veri Toplama Araçları}

Veriler, araştırmacılar tarafından hazırlanan "Kişisel Bilgi Formu" ve "Hemşire ve Ebelerin Kadına Yönelik Şiddet Belirtilerini Tanımalarına İlişkin Ölçek (HEKYŞBTÖ)" kullanılarak toplanmıştır.

Kişisel Bilgi Formu: Araştırmacılar tarafından literatür bilgileri doğrultusunda hazırlanmıştır (21-23). Bu form hemşire, ebe ve hekimlerin tanıtıcı ve mesleki özellikleri (cinsiyet, medeni durum, yaş, öğrenim durumu), kadına yönelik şiddete ilişkin eğitim alma durumları ve yaklaşımlarına yönelik sorulardan oluşmuştur.

Hemşire ve Ebelerin Kadına Yönelik Şiddet Belirtilerini Tanımalarına İlişkin Ölçek (HEKYŞBTÖ): Arabacı Baysan ve Karadağlı (24) tarafından 2006 yılında geliştirilen ölçek toplam 31 maddeden oluşmaktadır. Ölçeğin, "Fiziksel Belirtiler" ve "Duygusal Belirtiler" olmak üzere iki alt boyutu bulunmaktadır. Ölçekteki 1., 2 ., 25.,27.,28., ile 4-11 arasındaki maddeler ölçeğin "Fiziksel Belirtiler", 3., 26., ile 12-24 ve 29-31 arasındaki maddeler "Duygusal Belirtiler" alt boyutunu oluşturmaktadır. Ölçekteki maddeler "doğru” ve "yanlış" şeklinde cevaplanmaktadır. Yanıtların değerlendirilmesinde pozitif ifadelere (1., 3., 4., 5., 7., 10., 12., 16., 17., 18., 20., 21., 22., 24., 25., 26., 27., 28., 29. maddeler) "doğru" seçeneğine " 1 " puan, "yanlış" seçeneğine " 0 ” puan verilerek, negatif ifadelerde (2., 6., 8., 9., 11., 13., 14., 15., 19., 23., 30., 31. maddeler) tam tersi bir puanlama ("doğru” seçeneğine " 0 " puan, "yanlış" seçeneğine " 1 " puan) yapılarak yanıtlar sayısal değerlere dönüştürülmektedir. Ölçekten elde edilecek toplam puan 0-31, fiziksel belirtiler alt boyutu için 0-18 ve duygusal belirtiler alt boyut için 0-13 puanlar arasındadır. Puan yükseldikçe kadına yönelik şiddet belirtilerini tanımaya ilişkin bilgi düzeyi artmaktadır. Ölçeğin geçerlik güvenirlik çalışmasında Cronbach alfa katsayısı 0.76 olarak belirlenmiştir. HEKYŞBTÖ hemşire ve ebelere yönelik geliştirilen bir ölçek olmasına rağmen, literatürde hekimlere de uygulandığı görülmektedir (21-23). Bu çalışmada Cronbach alfa güvenirlik katsayısı 0.70 bulunmuştur.

\section{Veri Toplama Yöntemi}

Veriler, araştırmacılar tarafından ASM'lerde çalışan hemşire, ebe ve hekimler ziyaret edilerek toplanmıştır. Anket formlarının uygulanma süresi ortalama 10-15 dakika sürmüştür.

\section{İstatistiksel Analiz}

Verilerin analizinde SPSS 16.0 istatistik paket programı kullanılmıştır. Verilerin değerlendirilmesinde; yüzdelik dağılımlar, t testi, Mann Whitney U testi ve Kruskal Wallis $\mathrm{H}$ testi kullanılmıştır. $\mathrm{p}<0.05$ değeri anlamlı olarak kabul edilmiştir.

\section{BULGULAR}

Sağlık çalışanlarının yaş ortalamasının $45.33 \pm 7.69$ (minmaks: 26-66), \%62.2'sinin kadın ve \%90.4'ünün evli olduğu belirlenmiştir. Katılımcıların \% 48.9'unun hekim, \%41.5'inin ebe, \%9.6'sının hemşire olduğu, \%97'sinin 5 yıldan daha fazla süredir çalıştığı saptanmıştır. Sağlık çalışanlarının \%84.4'ünün mezuniyet öncesi, \%83.7'sinin mezuniyet sonrası kadına yönelik şiddet konusunda eğitim almadığı bulunmuştur. Katılımcıların \%72.6'sının iş yaşamında kadına yönelik şiddet olgusu/şüphesi ve \%64.4'ünün 1-10 arası olgu ile karşılaştı̆̆ 1 , \%51.1'inin ilgili kurumlara rapor etme/yasal süreçte, $\% 24.5$ 'inin ise öykü almada zorlandığı belirlenmiştir. Sağlık çalışanlarının \%51.1'inin çalışılan kurumda kadına yönelik şiddete ilişkin talimat/prosedür olduğunu belirttiği, \%69.6'sının kadına yönelik şiddet olgusu/şüphesi ile karşılaşıldığında bildirim yaptığı, bildirim yapmayanların \%8.9'u gerekçe olarak mağduru şimdiki bulunduğu durumdan daha kötü duruma sokmaktan korktuğunu belirtmiştir (Tablo 1).

Katılımcıların HEKYŞBTÖ toplam puan ortalamasının $19.06 \pm 3.68$, fiziksel belirtiler alt ölçek puan ortalamasının $8.07 \pm 1.68$, duygusal belirtiler alt ölçek puan ortalamasının $10.99 \pm 2.66$ olduğu bulunmuştur (Tablo 2).

Sağlık çalışanlarının sosyo-demografik ve mesleki özellikleri ile HEKYŞBTÖ ve alt boyutlarından aldıkları toplam puan ortalamaları incelendiğinde (Tablo 3); erkek sağlık çalışanlarının HEKYŞBTÖ toplam puan ortalaması $19.78 \pm 3.66$, fiziksel belirtiler alt boyut puan ortalamas1 $8.35 \pm 1.67$, duygusal belirtiler alt boyut puan ortalamas1 $11.43 \pm 2.74$ olarak bulunmuştur. Hekimlerin HEKYSBTÖ toplam puan ortalamasinın $19.45 \pm 3.9$, fiziksel belirtiler alt boyut puan ortalamasının $8.21 \pm 1.69$, duygusal belirtiler alt boyut puan ortalamasının $11.24 \pm 2.95$ olduğu saptanmıştır. Hemşirelerin HEKYŞBTÖ toplam puan ortalamasının $18.30 \pm 3.85$, fiziksel belirtiler alt boyut puan ortalamasının $7.84 \pm 2.30$, duygusal belirtiler alt boyut puan ortalamasının $10.46 \pm 2.14$ olduğu saptanmıştır. Meslekte çalışma süresi 5 yıldan az olan sağlık çalışanlarının HEKYŞBTÖ toplam puan ortalaması $20.00 \pm 4.24$, fiziksel belirtiler alt boyut puan ortalamas $7.75 \pm 1.50$, duygusal belirtiler alt boyut puan ortalaması $12.25 \pm 2.98$ olarak bulunmuştur. Mezuniyet öncesi kadına yönelik şiddet konusunda eğitim alanların toplam puan ortalaması $18.76 \pm 4.20$, fiziksel belirtiler alt boyut puan ortalamas1 $8.23 \pm 1.89$, duygusal belirtiler alt boyut puan ortalamas1 $10.52 \pm 3.05$ olarak saptanmıştır. Mezuniyet sonrasında kadına yönelik şiddet konusunda sertifikalı bir eğitim alan ve iş yaşamı boyunca kadına yönelik şiddet olgusu/şüphesi ile karşılaşan katılımcıların ölçekten ve alt boyutlarından aldığı puan ortalamalarının daha yüksek olduğu belirlenmiştir. Sağlık çalışanlarının çalışılan kurumda kadına yönelik şiddete ilişkin talimat/prosedür olduğunu belirtenlerin

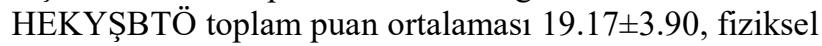
belirtiler alt boyutu puan ortalamas1 $8.20 \pm 1.77$, duygusal belirtiler alt boyut puan ortalaması $10.97 \pm 2.81$ olarak bulunmuştur. Kadına yönelik şiddet olgusu/şüphesi ile karşılaştığında bildirim yapacağını belirten katılımcıların HEKYŞBTÖ toplam ve alt boyutları puan ortalamalarının daha yüksek olduğu belirlenmiştir. Araştırmada sağlık çalışanlarının sosyo-demografik ve mesleki özellikleri ile HEKYŞBTÖ ve alt boyutlarından aldıkları toplam puan ortalamaları arasındaki farkın istatistiksel olarak anlamsız olduğu saptanmıştır ( $\mathrm{p}>0.05)$. 
Tablo 1. Sağlık çalışanlarının sosyo-demografik ve mesleki özelliklerinin dağılımı

\begin{tabular}{|c|c|c|c|}
\hline Özellikler (n=135) & & $\mathbf{n}$ & $\%$ \\
\hline \multirow{2}{*}{ Cinsiyet } & Erkek & 51 & 37.8 \\
\hline & Kadın & 84 & 62.2 \\
\hline \multirow[b]{2}{*}{ Medeni Durum } & Evli & 122 & 90.4 \\
\hline & Bekâr & 13 & 9.6 \\
\hline \multirow{3}{*}{ Meslek } & Hemşire & 13 & 9.6 \\
\hline & Ebe & 56 & 41.5 \\
\hline & Hekim & 66 & 48.9 \\
\hline \multirow{3}{*}{ Eğitim Durumu } & Sağlık Meslek Lisesi & 13 & 9.6 \\
\hline & Ön Lisans & 28 & 20.7 \\
\hline & Lisans ve üzeri & 94 & 69.7 \\
\hline \multirow{2}{*}{ Meslekteki çalışma süresi } & 5 y1ldan az & 4 & 3.0 \\
\hline & 5 yil ve üzeri & 131 & 97.0 \\
\hline \multirow{2}{*}{$\begin{array}{l}\text { Mezuniyet öncesi kadına yönelik şiddet } \\
\text { konusunda eğitim alma }\end{array}$} & Evet & 21 & 15.6 \\
\hline & Hayır & 114 & 84.4 \\
\hline \multirow{2}{*}{$\begin{array}{l}\text { Mezuniyet sonrasında kadına yönelik şiddet } \\
\text { konusunda sertifikalı bir eğitim alma }\end{array}$} & Evet & 22 & 16.3 \\
\hline & Hayır & 113 & 83.7 \\
\hline \multirow{2}{*}{$\begin{array}{l}\text { İş yaşamı boyunca kadına yönelik şiddet } \\
\text { olgusu/şüphesi ile karşılaşma }\end{array}$} & Evet & 98 & 72.6 \\
\hline & Hayır & 37 & 27.4 \\
\hline \multirow{2}{*}{ Karşılaşılan olgu sayısı $(\mathrm{n}=98)$} & $1-10$ & 87 & 64.4 \\
\hline & 11 ve üzeri & 11 & 8.2 \\
\hline \multirow{5}{*}{$\begin{array}{l}\text { İş yaşamı boyunca kadına yönelik şiddet } \\
\text { olgusu/şüphesi ile karşılaşmada zorlanılan } \\
\text { veya yetersiz kalınan aşamalar }(\mathbf{n}=98)\end{array}$} & Öykü alma & 24 & 24.5 \\
\hline & Fizik muayene & 3 & 3.1 \\
\hline & Ruhsal muayene & 9 & 9.1 \\
\hline & Kayit & 8 & 8.2 \\
\hline & İlgili kurumlara rapor etme/Yasal süreç & 54 & 55.1 \\
\hline \multirow{3}{*}{$\begin{array}{l}\text { Çalışılan kurumda kadına yönelik şiddete } \\
\text { ilişkin talimat/prosedür olması }\end{array}$} & Evet & 69 & 51.1 \\
\hline & Hayır & 28 & 20.7 \\
\hline & Bilmiyorum & 38 & 28.2 \\
\hline \multirow{2}{*}{$\begin{array}{l}\text { Kadına yönelik şiddet olgusu/şüphesi ile } \\
\text { karşılaşıldığında bildirim yapma durumu }\end{array}$} & Evet & 94 & 69.6 \\
\hline & Hayır & 41 & 30.4 \\
\hline \multirow{6}{*}{ Neden bildirim yapılmadığı $(n=41)$} & $\begin{array}{l}\text { Sosyal servislerin konuyla ilgilenemeyeceğini } \\
\text { düşünme }\end{array}$ & 10 & 7.4 \\
\hline & Sorunu mağdurun kendisinin daha iyi & & \\
\hline & çözebileceğini düşünme & 4 & 3.0 \\
\hline & Yasal süreçlere ait bilginin olmaması & 5 & 3.7 \\
\hline & $\begin{array}{l}\text { Mağduru şimdiki bulunduğu durumda daha kötü } \\
\text { duruma sokacağından korkma }\end{array}$ & 12 & 8.9 \\
\hline & Kime bildireceğini bilmeme & 10 & 7.4 \\
\hline
\end{tabular}

Tablo 2. HEKYŞBTÖ ve alt boyut puan ortalamalarının dağılımı

\begin{tabular}{cccc} 
HEKYŞBTÖ & $\begin{array}{c}\text { Alınabilecek } \\
\text { En küçük-En büyük } \\
\text { Değer }\end{array}$ & $\begin{array}{c}\text { İşaretlenen } \\
\text { En küçük-En büyük } \\
\text { Değer }\end{array}$ & Ortalama \pm Standart Sapma \\
\hline Fiziksel Belirtiler & $0-18$ & $5-17$ & $8.07 \pm 1.6$ \\
\hline Duygusal Belirtiler & $0-13$ & $3-12$ & $10.99 \pm 2.6$ \\
\hline Toplam & $0-31$ & $11-27$ & $19.06 \pm 3.6$
\end{tabular}

\section{TARTIŞMA}

Kadına yönelik şiddet, küresel bir sağlık sorunudur. Aynı zamanda kadınların insan haklarını ihlal etmektedir. Özellikle birinci basamak sağlık kurumlarında çalışan sağlık profesyonelleri sıklıkla ve kimi zaman farkında olmadan şiddet mağduru kadınlarla karşılaşmaktadır (25). $\mathrm{Bu}$ nedenle sağlık çalışanlarının kadına yönelik şiddet belirtilerini tanımaları önemlidir. Belirtilerin tanınabilmesi için yeterli bilgiye sahip olunması gerekmektedir (26).

Çalışmamızda sağlık profesyonellerinin çoğunun (\%84.4) mezuniyet öncesi kadına yönelik şiddet konusunda eğitim almadığı görülmektedir. Yapılan bir çalışmada, hemşire ve ebelerin \%55.8'inin mezuniyet öncesi kadına yönelik şiddet konusunda eğitim almadığı bulunmuştur (27). Yapılan bir başka çalışmada, hemşire ve ebelerin okulda aldıkları eğitim oranlarının düşük olduğu (\%17.4), verilen eğitimin yetersiz olduğunu düşündükleri saptanmıştır (28). Hemşirelik öğrencileriyle yapılan bir çalışmada, öğrencilerin \%61.7'si ders müfredatı içerisinde kadına yönelik şiddet dersi olmasını, \%70.4'ü kadına yönelik şiddet konusunda daha fazla bilgi sahibi olmak istediğini belirtmiştir (29). Kanbay ve ark. (30)'nın çalışmasında, hemşirelik öğrencilerinin 
\%54.3'ünün daha önce kadına yönelik şiddetle ilgili bir eğitim programına katılmadığı bulunmuştur. Sağlık profesyonelleriyle yapılan başka çalışmalar da araştırma bulgusuyla benzerlik göstermektedir $(22,23,31,32)$. Çalışma bulgusundan farklı olarak Öztürk ve Toprak (8)'ın çalışmasında katılımcıların \%12.3'ünün mezuniyet öncesi eğitim almadığ 1 saptanmıştır. Frank ve ark. (33)'nın tıp fakültesi öğrencileriyle yaptığı çalışmada katılımcıların çoğu (\%91) kadına yönelik eş/sevgili şiddeti hakkında bilgi aldığını bildirmiştir.
Araştırma sonucumuz ve diğer çalışmalar göz önüne alındığında, hemşire, ebe ve hekimlerin çoğunun mesleki eğitim sürecinde kadına yönelik şiddete ilişkin eğitim almadıkları görülmektedir. Şiddet mağduru kadınların birinci basamak sağlık kurumlarına başvurdukları bildirilmektedir (8,13-15). Bu nedenle aile sağlı̆̆ merkezlerinde çalışan sağlık profesyonellerinin kadına yönelik şiddeti tanımada yeterli bilgi ve donanıma sahip olması için mezuniyet öncesi dönemdeki eğitimde kadına yönelik şiddet konusunun daha fazla yer alması gerektiği düşünülmektedir.

Tablo 3. Sağlık çalışanlarının sosyo-demografik ve mesleki özellikleri ile HEKYŞBTÖ ve alt boyutlarından aldıkları puan ortalamalarının karşılaştırılması

\begin{tabular}{|c|c|c|c|c|}
\hline Özellikler & & $\begin{array}{l}\text { HEKYŞBTÖ } \\
\text { Toplam }\end{array}$ & $\begin{array}{c}\text { Fiziksel } \\
\text { Belirtiler Alt } \\
\text { Boyut } \\
\end{array}$ & $\begin{array}{c}\text { Duygusal } \\
\text { Belirtiler Alt } \\
\text { Boyut } \\
\end{array}$ \\
\hline \multirow{4}{*}{ Cinsiyet } & Erkek & $19.78 \pm 3.66$ & $8.35 \pm 1.67$ & $11.43 \pm 2.74$ \\
\hline & Kadın & $18.63 \pm 3.65$ & $7.90 \pm 1.68$ & $10.72 \pm 2.59$ \\
\hline & & $\mathrm{t}=1.770$ & $\mathrm{t}=1.504$ & $\mathrm{t}=1.496$ \\
\hline & & $\mathrm{p}=0.078$ & $\mathrm{p}=0.135$ & $\mathrm{p}=0.137$ \\
\hline \multirow{4}{*}{ Medeni Durum } & Evli & $19.24 \pm 3.62$ & $8.17 \pm 1.71$ & $11.07 \pm 2.60$ \\
\hline & Bekâr & $17.38 \pm 3.96$ & $7.15 \pm 0.98$ & $10.23 \pm 3.19$ \\
\hline & & $M W-U=523.5$ & $\mathrm{MW}-\mathrm{U}=481.0$ & $M W-U=593.0$ \\
\hline & & $\mathrm{p}=0.050$ & $\mathrm{p}=0.060$ & $\mathrm{p}=0.133$ \\
\hline \multirow{5}{*}{ Meslek } & Hemşire & $18.30 \pm 3.85$ & $7.84 \pm 2.30$ & $10.46 \pm 2.14$ \\
\hline & Ebe & $18.78 \pm 3.36$ & $7.96 \pm 1.52$ & $10.82 \pm 2.41$ \\
\hline & Hekim & $19.45 \pm 3.90$ & $8.21 \pm 1.69$ & $11.24 \pm 2.95$ \\
\hline & & $\mathrm{KW}=1.429$ & $\mathrm{KW}=0.235$ & $\mathrm{KW}=2.215$ \\
\hline & & $\mathrm{p}=0.489$ & $\mathrm{p}=0.889$ & $\mathrm{p}=0.330$ \\
\hline \multirow{5}{*}{ Eğitim Durumu } & Sağlık Meslek Lisesi & $18.15 \pm 2.79$ & $7.23 \pm 1.48$ & $10.92 \pm 1.75$ \\
\hline & Ön Lisans & $18.82 \pm 3.81$ & $8.10 \pm 1.74$ & $10.71 \pm 2.62$ \\
\hline & Lisans ve üzeri & $19.26 \pm 3.76$ & $8.18 \pm 1.67$ & $11.08 \pm 2.79$ \\
\hline & & $\mathrm{KW}=1.332$ & $\mathrm{KW}=3.129$ & $\mathrm{KW}=0.555$ \\
\hline & & $\mathrm{p}=0.514$ & $\mathrm{p}=0.209$ & $\mathrm{p}=0.758$ \\
\hline \multirow{4}{*}{ Meslekteki çalışma süresi } & 5 yildan az & $20.00 \pm 4.24$ & $7.75 \pm 1.50$ & $12.25 \pm 2.98$ \\
\hline & 5 y1l ve üzeri & $19.03 \pm 3.68$ & $8.08 \pm 1.69$ & $10.95 \pm 2.65$ \\
\hline & & $M W-U=231.5$ & $M W-U=233.0$ & MW-U $=202.5$ \\
\hline & & $\mathrm{p}=0.691$ & $\mathrm{p}=0.701$ & $\mathrm{p}=0.437$ \\
\hline \multirow{4}{*}{$\begin{array}{l}\text { Mezuniyet öncesi kadına yönelik şiddet } \\
\text { konusunda eğitim alma }\end{array}$} & Evet & $18.76 \pm 4.20$ & $8.23 \pm 1.89$ & $10.52 \pm 3.05$ \\
\hline & Hayır & $19.12 \pm 3.59$ & $8.04 \pm 1.65$ & $11.07 \pm 2.59$ \\
\hline & & MW-U $=749.0$ & MW-U=974.5 & MW-U $=769.5$ \\
\hline & & $\mathrm{p}=0.672$ & $\mathrm{p}=0.785$ & $\mathrm{p}=0.439$ \\
\hline \multirow{4}{*}{$\begin{array}{l}\text { Mezuniyet sonrasında kadına yönelik şiddet } \\
\text { konusunda sertifikalı bir eğitim alma }\end{array}$} & Evet & $19.34 \pm 3.68$ & $8.16 \pm 1.68$ & $11.18 \pm 2.69$ \\
\hline & Hayır & $18.32 \pm 3.62$ & $7.83 \pm 1.69$ & $10.48 \pm 2.55$ \\
\hline & & $\mathrm{t}=1.444$ & $\mathrm{t}=1.000$ & $\mathrm{t}=1.359$ \\
\hline & & $\mathrm{p}=0.151$ & $\mathrm{p}=0.319$ & $\mathrm{p}=0.176$ \\
\hline \multirow{4}{*}{$\begin{array}{l}\text { İş yaşamı boyunca kadına yönelik şiddet } \\
\text { olgusu/şüphesi ile karşılaşma }\end{array}$} & Evet & $19.34 \pm 3.68$ & $8.16 \pm 1.68$ & $11.18 \pm 2.69$ \\
\hline & Hayır & $18.32 \pm 3.62$ & $7.83 \pm 1.69$ & $10.48 \pm 2.55$ \\
\hline & & $\mathrm{t}=1.444$ & $\mathrm{t}=1.000$ & $\mathrm{t}=1.359$ \\
\hline & & $\mathrm{p}=0.151$ & $\mathrm{p}=0.319$ & $\mathrm{p}=0.176$ \\
\hline \multirow{4}{*}{ Karşılaşılan olgu sayısı $(n=98)$} & $1-10$ & $19.26 \pm 3.63$ & $8.12 \pm 1.62$ & $11.13 \pm 2.69$ \\
\hline & 11 ve üzeri & $1.45 \pm 3.85$ & $8.27 \pm 2.10$ & $11.18 \pm 2.60$ \\
\hline & & MW-U $=469.0$ & $M W-U=452.5$ & $\mathrm{MW}-\mathrm{U}=467.0$ \\
\hline & & $\mathrm{p}=0.915$ & $\mathrm{p}=0.765$ & $\mathrm{p}=0.896$ \\
\hline \multirow{5}{*}{$\begin{array}{l}\text { Çalışılan kurumda kadına yönelik şiddete } \\
\text { ilişkin talimat/prosedür olması }\end{array}$} & Evet & $19.17 \pm 3.90$ & $8.20 \pm 1.77$ & $10.97 \pm 2.81$ \\
\hline & Hayır & $18.82 \pm 4.16$ & $7.53 \pm 1.71$ & $11.28 \pm 2.99$ \\
\hline & Bilmiyorum & $19.05 \pm 2.90$ & $8.23 \pm 1.45$ & $10.81 \pm 2.14$ \\
\hline & & $\mathrm{KW}=0.078$ & $\mathrm{KW}=2.254$ & $\mathrm{KW}=0.839$ \\
\hline & & $\mathrm{p}=0.962$ & $\mathrm{p}=0.324$ & $\mathrm{p}=0.657$ \\
\hline \multirow{4}{*}{$\begin{array}{l}\text { Kadına yönelik şiddet olgusu/şüphesi ile } \\
\text { karşılaşıldığında bildirim yapma durumu }\end{array}$} & Evet & $19.15 \pm 3.60$ & $8.10 \pm 1.60$ & $11.05 \pm 2.70$ \\
\hline & Hayır & $18.55 \pm 3.90$ & $8.00 \pm 1.87$ & $10.85 \pm 2.60$ \\
\hline & & $\mathrm{t}=1.442$ & $\mathrm{t}=1.336$ & $\mathrm{t}=1.399$ \\
\hline & & $\mathrm{p}=0.659$ & $\mathrm{p}=0.738$ & $\mathrm{p}=0.691$ \\
\hline
\end{tabular}

t: t-testi, MW-U: Mann Whitney U testi, KW: Kruskal Wallis testi, HEKYŞBTÖ: Hemşire ve Ebelerin Kadına Yönelik Şiddet Belirtilerini Tanımalarına İlişkin Ölçek 
Çalışmamızda katılımcıların \%83.7'sinin mezuniyet sonrası kadına yönelik şiddet konusunda sertifikalı bir eğitim almadığı belirlenmiştir. Yayla (23)'nın çalışmasında, katılımcıların neredeyse tamamının (\%98.5) mezuniyet sonrası sertifikalı bir eğitim almadığ saptanmıştır. Othman ve Mat Adenan (34)'ın çalışmasında, hekimlerin \%80'inin hemşirelerin \%93.2'sinin aile içi şiddetle ilgili herhangi bir eğitim programına katılmadığı belirlenmiştir. Kıyak ve Akın (28) ile Orhan ve Gölbaşı (35)'nın çalışması da araştırma bulgusu ile benzerlik göstermektedir. Literatürde araştırma bulgumuzdan farklı olarak sağlık profesyonellerinin mezuniyet sonrası şiddete yönelik eğitime katılma oranlarının yüksek olduğu çalışmalar da bulunmaktadır $(21,22,36)$.

Araştırmamızda sağlık çalışanlarının \%72.6'sının iş yaşamı boyunca kadına yönelik şiddet olgusu/şüphesi ile karşılaştığ 1 saptanmıştır. Hemşire, ebe ve hekimlerle yapılan bir çalışmada katılımcıların \%71.3'ünün kadına yönelik şiddet olgusu ile karşılaştığı bulunmuştur (22). Yapılan başka çalışmalarda da sağlık çalışanlarının kadına yönelik şiddet olgusu ile karşılaşma oranlarının yüksek olduğu belirlenmiştir $(2,23)$.

Araştırmamızda sağlık profesyonellerinin iş yaşamı boyunca kadına yönelik şiddet olgusu/şüphesi ile karşılaştığında en fazla "ilgili kurumlara rapor etme/yasal süreç” (\%51.1) ve "öykü alma” da (\%24.5) zorlandıkları görülmektedir. Yayla (23)'nın çalışmasında, hemşirelerin $\% 90.5$ 'i, ebelerin \%87.9'u, hekimlerin ise \%91.6'sı kadına yönelik şiddet olgusu ile karşılaştıklarında zorlandıklarını ve kendilerini yetersiz hissettiklerini belirtmişlerdir. Ayrica, katılımciların \%24.6'sının rapor etme/yasal süreçte, \%34.8'inin öykü almada zorlandığı bulunmuştur. Araştırma bulgumuzun aksine Öztürk ve ark. (8)'nın kadın sağlı personelleriyle (doktor ve hemşire) yaptığ çalışmada, mağdurun ifade etmediği ama kendisinin şüphelendiği durumda katılımcıların \%25.5'inin rapor tutacağını ifade ettiği belirlenmiştir. Yapılan bir çalışmada yetersiz kalma ve zorlanmanın hekimlerin \%65.6'sında zaman azlığ1, \%52.5'inde hastaları incitmekten korkmak, \%32.8'inde soruları nasıl soracağından emin olamamaktan kaynaklandığı belirtilmektedir (34). Araştırmamızda sağlık çalışanlarının bildirim yapmakta zorlanma nedenlerinin eğitim eksikliğinden kaynaklandığ düşünülmektedir.

Araştırmamızda HEKYŞBTÖ toplam puan ortalamasının $19.06 \pm 3.68$, fiziksel belirtiler alt boyut puan ortalamasının $8.07 \pm 1.68$, duygusal belirtiler alt boyut puan ortalamasının $10.99 \pm 2.66$ olduğu saptanmıştır. Bu sonuçlar ASM'lerde çalışan sağlık çalışanlarının kadına yönelik şiddet belirtilerini tanımalarına ilişkin bilgi düzeylerinin kısmen yeterli olduğunu göstermektedir. Çalışma bulgusuna benzer şekilde Sarıbıyık (22)'ın Malatya merkez ASM'lerde çalışan hemşire, ebe ve hekimlerle yaptı̆̆ 1 çalışmada, katılımcıların HEKYŞBTÖ toplam puanı 18.6 \pm 3.7 olarak bulunmuştur. Yayla (23)'nın çalışmasında hemşire ve hekimlerin HEKYŞBTÖ toplam puan ortalaması $18.83 \pm 3.38$ olarak saptamıştır. Arabacı ve Karadağlı (24)'nın hemşire ve ebeler ile yaptıkları çalışmada toplam ölçek puan ortalaması 18.38 \pm 5.23 olarak bulunmuştur. Ülkemizde yapılmış başka çalışmaların sonuçları da araştırma bulgumuz ile benzerlik göstermektedir $(21,23)$.
Çalışmamızda erkeklerin HEKYŞBTÖ ve alt boyut puan ortalamalarının daha yüksek bulunsa da aradaki farkın istatistiksel olarak anlamsız olduğu bulunmuştur $(\mathrm{p}>0.05)$. Benzer şekilde hemşire ve ebelerle yapılan bir çalışmada (31), erkek sağlık çalışanlarının HEKYŞBTÖ toplam puan ortalaması ve duygusal belirtiler alt ölçek puan ortalamasının daha yüksek olduğu, ancak cinsiyet farkının kadına yönelik şiddeti tanımada etkili olmadığı belirlenmiştir. Çatak Taşkıran'ın sağlık çalışanlarıyla (hekim, hemşire ve ebe) yaptığı araştırmada (21), ölçek toplam ve alt boyut puan ortalamaları ile cinsiyet arasında anlamlı bir fark bulunmamıştır ( $\mathrm{p}>0.05)$.

Araştırmamızda hekimlerin HEKYŞBTÖ toplam, fiziksel ve duygusal alt ölçek puan ortalamalarının daha yüksek olduğu, ancak meslek ile HEKYŞBTÖ ve alt boyut puan ortalaması arasındaki farkın istatistiksel olarak anlamsız olduğu bulunmuştur $\quad(\mathrm{p}>0.05)$. Sarıbıyık (22)'ın çalışmasında, duygusal belirtiler alt boyut puan ortalamasının hekimlerde, toplam puan ortalamasinın hemşirelerde en yüksek olduğu ve aradaki farkın istatistiksel olarak anlamlı olduğu belirlenmiştir $(p<0.05)$. Kahyaoğlu Süt ve Akyüz (31)'ün çalışmasında, hemşirelerin puan ortalamalarının daha yüksek olduğu ve meslek ile sadece fiziksel belirtiler alt boyut puan ortalaması arasındaki farkın istatistiksel olarak anlamsız olduğu bulunmuştur ( $\mathrm{p}>0.05)$. Çalışmamızda hekimlerin ölçek puan ortalamalarının daha yüksek bulunması, araştırmaya katılan hekimlerin sayısının daha fazla olmasından kaynaklanabilir. Ayrıca tıp eğitimi sırasında hekimlerin adli tıp dersi aldığı ve ders içeriğine bağlı olarak bu konuda farkındalıklarının daha iyi olduğu da düşünülmektedir. Yapılan çalışmalarda hemşire ve ebelerin kadına yönelik şiddet konusunda eğitim almadıkları ve ders içeriklerinin kadına yönelik şiddeti tanımaları için yetersiz olduğu vurgulanmaktadır (29-31). Meslekte çalışma süresi 5 yıldan az olanların HEKYŞBTÖ toplam ve duygusal belirtiler alt boyut puan ortalamalarının daha yüksek olduğu, fiziksel alt boyut puan ortalamasının ise daha düşük olduğu saptanmıştır. Meslekte çalışma süresi ile ölçek toplam ve alt boyut puan ortalamaları arasındaki farkın istatistiksel olarak anlamsız olduğu belirlenmiştir ( $\mathrm{p}>0.05)$. Kıyak ve Akın (28)'ın çalışmasında, hemşire ve ebelerin birinci basamakta çalışma süresi fiziksel şiddet belirtilerini tanımada önemli bulunmuş, meslekte çalışma süresi 6-10 yıl olanların fiziksel belirtileri tanıma puanları 11-15 yil olanlardan yüksek ve aradaki fark istatistiksel olarak anlamlı olduğu belirlenmiştir $(p<0.01)$. Sağlık çalışanlarıyla yapılan bir başka çalışmada (22), 6-14 yıl çalışan katılımcıların toplam puan ortalamaları daha yüksek, aradaki farkın anlamsız olduğu saptanmıştır ( $\mathrm{p}>0.05)$. Araştırmamızda, katılımcıların meslekte çalışma süresi arttıkça kadına yönelik şiddetin fiziksel belirtilerini tanımaları artmaktadır. Bu sonuç, çalışma yılı arttıkça karşılaşılan olgu sayısının artmasından ve mesleki deneyimin sağladığı daha profesyonel bir yaklaşım ile kadınların değerlendirilebilmesinden kaynaklanıyor olabilir.

Araştırmamızda, mezuniyet öncesi eğitim alan sağlık çalışanlarının ölçek toplam ve duygusal belirtiler alt boyut puan ortalamalarının daha düşük bulunsa da aradaki farkın istatistiksel olarak anlamsız olduğu belirlenmiştir ( $>0.05)$. Bu sonuç mezuniyet öncesi kadına yönelik şiddetle ilgili verilen eğitimin yetersiz olduğunu 
düşündürmektedir. Hemşirelik öğrencileriyle yapılan bir çalışmada (29), öğrencilerin \%61.7'si ders müfredatı içerisinde kadına yönelik şiddet dersinin olmasını ve \%70.4'ü kadına yönelik şiddet konusunda daha fazla bilgi sahibi olmak istediğini belirtmiştir. Başka bir çalışmada (28), hemşire ve ebelerin kadına yönelik şiddete ilişkin aldıkları eğitim oranlarının düşük olduğu ve verilen eğitimin yetersiz olduğunu düşündükleri bulunmuştur.

Mezuniyet sonrası sertifikalı bir eğitim alanların HEKYŞBTÖ toplam, fiziksel ve duygusal belirtiler alt boyut puan ortalamalarının daha yüksek olduğu, ancak aradaki farkın istatistiksel olarak anlamsız olduğu saptanmıştır $(\mathrm{p}>0.05)$. Benzer şekilde Sarıbıyık (22)'ın çalışmasında, mezuniyet sonrası eğitim alanların ölçek toplam puan ortalamalarının daha yüksek ve aradaki farkın istatistiksel olarak anlamsız olduğu bulunmuştur. $\mathrm{Bu}$ sonuç mezuniyet sonrası verilen eğitimin ciddi düzeyde fark yaratmasa da etkin olduğunu göstermektedir.

Çalışmamızda, iş yaşamı boyunca kadına yönelik şiddet olgusu/şüphesi ile karşılaşan sağlık profesyonellerinin ölçek puan ortalamalarının daha yüksek ancak aradaki farkın istatistiksel olarak anlamsız olduğu belirlenmiştir $(p>0.05)$. Yapılan bir çalışmada (22) da, iş yaşamı boyunca kadına yönelik şiddet olgusu/şüphesi ile karşılaşanların toplam puan ortalamalarının daha yüksek olmasına rağmen aradaki farkın istatistiksel olarak anlamsız olduğu bulunmuştur $(\mathrm{p}>0.05)$. Bu durumun iş yaşamı boyunca kadına yönelik şiddet olgusu/şüphesi ile karşılaşan sağlık personelinin kadına yönelik şiddet belirtilerine yönelik deneyim ve tecrübe sahibi olmasından kaynaklandığı düşünülmektedir.

Araştırmamızda, kadına yönelik şiddet olgusu/şüphesi ile karşılaştığında bildirim yapanların ölçek ve alt boyut toplam puan ortalamalarının daha yüksek olmasına rağmen aradaki farkın istatistiksel olarak anlamsız olduğu bulunmuştur ( $>0.05$ ). Sarıbıyık (22)'ın çalışmasında, iş yerinde kadına yönelik şiddet ile ilgili prosedür olduğunu belirtenlerin bildirim yapma oranlarının daha yüksek olduğu (\%90.6) belirlenmiştir. Kıyak ve Akın (28)'ın çalışmasında, şiddete uğramış bir kadınla karşılaştığında girişimde bulunmayı mesleki sorumluluk olarak gören sağlık profesyonellerinin toplam ve duygusal belirtiler alt boyut puan ortalamalarının daha yüksek ve aradaki farkın anlamsız olduğu bulunmuştur ( $>0.05)$. Araştırma sonuçları da çalışma bulgumuzu desteklemektedir. Elde edilen sonuçlara bakıldığında, sağlık profesyonellerinin kurumsal mekanizmaların farkında, toplumsal duyarlılık ve görev bilinci ile sorumluluklarını yerine getirdiği söylenebilir.

\section{SONUÇ}

Çalışmamızda Aile Sağlığı Merkezleri’nde görev yapan sağlık çalışanlarının kadına yönelik şiddet belirtilerini tanımalarına ilişkin bilgi düzeylerinin kısmen yeterli olduğu bulunmuştur. Sağlık çalışanlarının sosyo-demografik ve mesleki özellikleri ile HEKYŞBTÖ ve alt boyutları arasında anlamlı bir fark olmadığı belirlenmiştir. Sağlık profesyonellerinin kadına yönelik şiddet belirtilerini tanımalarına ilişkin bilgi düzeylerinin kısmen yeterli olduğu göz önüne alınarak, eğitim programlarında kadına yönelik şiddetle ilgili derslere yer verilmesi, şiddet mağduru kadınların belirlenmesi ve bildirimlerin yapılması için sağlık profesyonellerine düzenli ve sürekli hizmet içi eğitimlerin kurumlarda yaygınlaştırılması önerilmektedir.

\section{Çıkar çatışması}

Herhangi bir çıkar çatışması veya anlaşmazlık bulunmamaktadır. "Sağlık Çalışanlarının Kadına Yönelik Şiddeti Tanımalarına İlişkin Bilgi Düzeylerinin Belirlenmesi" başlıklı çalışmamız ile ilgili olarak; Çalışma için ayni katkı veya parasal destek alınmamıştır.

\section{KAYNAKLAR}

1. Elmalı F, Erten ZK, Zincir H, Özen B, Balcı E. Hemşire ve Ebelerin Aile İçi Fiziksel Şiddete Bakış Açıları. Sağlık Bilimleri Dergisi. 2011; 20(1): 39-47.

2. Aba Yılda A, Karadağ Başar F. Sağlık Profesyonellerinin Aile İçi Şiddeti Tanılaması ve Yaklaşımlarının Belirlenmesi. STED. 2015; 24(4): 125-34.

3. Dişsiz M, Şahin NH. Evrensel Bir Kadın Sağlığ Sorunu: Kadına Yönelik Şiddet. Maltepe Üniversitesi Hemşirelik Bilim ve Sanatı Dergisi. 2008; 1(1): 51-8

4. Word Health Organization [Internet] Intimate Partner and Sexual Violence against Women [Cited: 2017 June 29]. Available from: http://www.who.int/mediacentre /factsheets/fs239/en/.

5. Şenol D, Yıldız S. Türk Tabipler Birliği.org [Internet]. Ankara: Kadına Yönelik Şiddet Algısı-Kadın ve Erkek Bakış Açılarıyla. Mutlu Çocuklar Derneği Yayınları [Son güncelleme tarihi: 2013; Erişim tarihi: 30 Ocak 2018]. Erişim adresi: https://www.ttb.org.tr/kutuphane /siginmacirpr.pdf.

6. Hacettepe. edu.tr [Internet]. Ankara: Türkiye'de kadına yönelik aile içi şiddet araştırması [Son güncelleme tarihi: 2013; Erişim tarihi: Ocak 2018]. Erişim adresi: http://www.hips.hacettepe.edu.tr/KKSA -TRAnaRaporKitap26Mart.pdf.

7. Krahe B. Violence against Women. Curr Opin Psychol. 2018; 19: 6-10.

8. Öztürk Ö, Öztürk Ö, Tapan B. Kadına Yönelik Şiddetin Kadın ve Toplum Sağlığı Üzerine Etkileri. Sağlik Akademisyenleri Dergisi. 2016; 3(4): 139-44.

9. Şimşek H. Toplumsal Cinsiyet Eşitsizliğinin Kadın Üreme Sağlığına Etkisi: Türkiye Örneği. DEÜ Tıp Fakültesi Dergisi. 2011; 25(2): 119-26.

10. Tetikcok R, Ozer E, Cakir L, İscanlı MD, Cankaya S, Ozer F. Violence towards Women is a Public Health Problem. Journal of Forensic and Leq Med. 2016; 44: 150-7.

11. Koyun A, Taşkın L, Terzioğlu F. Yaşam Dönemlerine Göre Kadın Sağlı̆̆ı ve Ruhsal İşlevler: Hemşirelik Yaklaşımlarının Değerlendirilmesi. Psikiyatride Güncel Yaklaşımlar. 2011; 3(1): 67-99.

12. Kadınınstatüsü.aile.gov.tr [Internet]. Ankara: Kadına Yönelik Şiddetle Mücadele Ulusal Eylem Planı 20162020 [Erişim tarihi: 22 Temmuz 2018]. Erişim adresi: https://kadininstatusu.aile.gov.tr/uploads/pages/dagiti mda-olan-yayinlar/kadina-yonelik-siddetle-mucadeleulusal-eylem-plani-2016-2020-icin-tiklayiniz.pdf.

13. Feder G, Ramsay J, Dunne D, Rose M, Arsene C, Norman R, et al. How Far Does Screening Women for Domestic (Partner) Violence in Different Health-Care Settings Meet Criteria for a Screening Programme? Systematic Reviews of Nine UK National Screening Committee Criteria. Health Technology Assessment. 2009; 13(16): iii-iv, xi-xiii, 1-113, 137-347. doi: 10.3310/hta13160. 
14. Bonomi AE, Anderson ML, Rivara FP, Thompson RS. Health Care Utilization and Costs Associated with Physical and Nonphysical-Only Intimate Partner Violence. Health Serv Res. 2009; 44(3): 1052-67.

15. Richardson J, Coid J, Petruckevitch A, Chung WS, Moorey S, Feder G. Identifying Domestic Violence: Cross Sectional Study in Primary Care. BMJ. 2002; 324(7332): 274-7.

16. Yavuz S, Aşırdizer, M. Celal Bayar Üniversitesi Tıp Fakültesi Adli Tıp Polikliniği'ne Başvuran Aileiçi Şiddete Maruz Kalmış Kadın Olgularının Analizi. Adli Tip Dergisi. 2009; 23(1): 15-23.

17. Şahin EM, Yetim D, Güleç Öyekçin D. Edirne'de Kadına Yönelik Eş Şiddet Yaygınlığı ve Kadınların Şiddete Karşı Tutumları. Cumhuriyet Tıp Dergisi. 2012; 34(1): 23-32.

18. Saglıkbakanligi.gov. tr [Internet]. Birimler [Erişim tarihi: 22 Ocak 2018]. Erişim adresi: https://hsgm.saglik.gov.tr/tr/birimler.html.

19. Gömbül Ö. Hemşirelerin Ailede Kadına Eşi Tarafindan Uygulanan Şiddete ve Şiddette Mesleki Role İlişkin Tutumları. Hemşirelikte Araştırma Geliştirme Dergisi (HEMAR-G). 2000; 2(1): 19-32.

20. Turktabiplerbirligi.gov.tr [Internet]. Hekimlerin Yasal Sorumlulukları [Erişim tarihi: 23 Ocak 2018]. Erişim adresi: https://www.ttb.org.tr/eweb/adli/1.html.

21. Çatak Taşkıran A. dl.handle.net [Internet]. Birinci Basamakta Çalışan Hekim, Ebe ve Hemşirelerin Kadına Yönelik Aile İçi Şiddeti Tanıma ve Bildirim Konusundaki Tutum ve Davranışları [Son güncelleme tarihi: 2015; Erişim tarihi: 30 Ocak 2018]. Erişim adresi: http://hdl.handle.net/11499/735.

22. Sarıbıyık M. Malatya Merkez Sağlık Ocaklarında Çalışan Hekim, Hemşire ve Ebelerin Şiddet Deneyimleri ve Kadına Yönelik Şiddetle İlgili Tutum ve Davranış Düzeyleri [Yüksek Lisans Tezi]. Malatya: İnönü Üniversitesi Sağlık Bilimleri Enstitüsü, Halk Sağlığı Ana Bilim Dalı; 2012.

23. Yayla ID. Hekim ve Hemşirelerin Kadına Yönelik Şiddet İle İlgili Bilgi, Tutum ve Davranış Düzeyleri [Yüksek Lisans Tezi]. İstanbul: Marmara Üniversitesi Sağlık Bilimleri Enstitüsü; 2009.

24. Baysan Arabacı L, Karadağlı A. Hemşire ve Ebelerin Kadına Yönelik Şiddet Belirtilerini Tanımalarına İlişkin Ölçek Geliştirme. Sağlık ve Toplum Dergisi. 2006; 16(2): 101-12.

25. Garcia-Moreno C, Hegarty K, d'Oliveira AFL, KoziolMcLain J, Colombini M, Feder G. The health-systems response to violence against women. Lancet. 2015; 385(9977): 1567-79. doi: 10.1016/S01406736(14)61837-7.

26. Christofides N, Silo Z. How Nurses' Experiences of Domestic Violence Influence Service Provision: Study Conducted in North-West Province South Africa. Nursing \& Health Sciences. 2005; 7(1): 9-14.

27. Şener N, Uncu F. Knowledge Levels of Nurses and Midwives Working in Family Practice about Violence to Woman. J Nurs Care. 2017; 6(4): 103.

28. Kıyak S, Akın B. Hemşire ve Ebelerin Kadına Yönelik Şiddet Konusunda Bilgi ve Tutumları. Hemşirelikte Araştırma Geliştirme Dergisi. 2010; 12(2): 5-16.

29. Sabancıoğulları S, Taşkın Yılmaz F, Ar E, Çakmaktepe G. Hemşirelik Öğrencilerinin Kadına Yönelik Şiddete ve Şiddette Mesleki Role İlişkin Tutumları, Benlik Saygıları ve Etkileyen Faktörler. Hemşirelikte Eğitim ve Araştırma Dergisi. 2016; 13(1): 35-43.

30. Kanbay Y, Işık E, Yavuzaslan M, Keleş S. Hemşirelik Öğrencilerinin Kadına Yönelik Aile İçi Şiddetle İlgili Görüş ve Tutumlarının Belirlenmesi. Gümüşhane Üniversitesi Sağlık Bilimleri Dergisi. 2012; 1(2): 10711.

31. Kahyaoğlu Süt H, Akyüz P. Hemşire ve Ebelerin Kadına Yönelik Şiddet Belirtilerini Tanımaya İlişkin Bilgi Düzeyleri. Uluslararası Hakemli Kadın Hastalıkları ve Anne Çocuk Sağlığı Dergisi (JACSD). 2016; 6(2): 1-15.

32. Gutmanis I, Beynon C, Tutty L, Wathen CN, MacMillanet HL. Factors Influencing Identification of and Response to Intimate Partner Violence: A Survey of Physicians and Nurses. BMC Public Health. 2007; 7(12): 1-11.

33. Frank E, Elon L, Saltzman LE, Houry D, McMahon P, Doyle J. Clinical and Personal Intimate Partner Violence Training Experiences of U.S. Medical Students. Journal of Women's Health. 2006; 15(9): 1071-9.

34. Othman S, Azmi N, Adenan M. Domestic Violence Management in Malaysia: A Survey on the Primary Health Care Providers. Asia Pacific Family Medicine. 2008; 7(2): 1-8.

35. Orhan AS, Gölbaşı Z. Birinci Basamak Sağlık Kurumlarında Çalışan Sağlık Personelinin Kadına Yönelik Aile İçi Şiddet Konusundaki Görüş ve Uygulamaları. Hemşirelikte Araştırma Geliştirme Dergisi. 2011;13(2): 21-32.

36. Moore ML, Zaccaro D, Parsons LH. Attitudes and Practices of Registered Nurses toward Women Who Have Experienced Abuse/Domestic Violence. J Obstet Gynecol Neonatal Nurs. 1998; 27(2): 175-82. 